\title{
Manajemen Mutu Dalam Peningktaan Kompetensi Profesional Guru Di Man 2 Model Medan \\ Riduan Pohan ${ }^{1}$, Muhammad Rizki ${ }^{2}$ \\ UIN Sumatera Utara, Medan
}

Corresponding Author $\otimes$ riduanpohan55@gmail.com

\begin{tabular}{|c|c|}
\hline & ABSTRACT \\
\hline $\begin{array}{l}\text { ARTICLE INFO } \\
\text { Article history: } \\
\text { Received } \\
\text { 02 January } 2021 \\
\text { Revised } \\
\text { 06 January 2021 } \\
\text { Accepted } \\
\text { 13 Desember } 2020\end{array}$ & $\begin{array}{l}\text { Quality management, and find efforts in improving teacher professional } \\
\text { competence in MAN } 2 \text { Model Medan. This type of research i s a } \\
\text { qualitative descriptive study that is a research procedure that produces } \\
\text { descriptive data in the form of written or oral words from people and } \\
\text { actors observed, directed from an individual's background as a whole } \\
\text { (holistically) without isolating the individual and his organization in a } \\
\text { variable but looking at it as part of a wholeness. This study uses } \\
\text { qualitative techniques in data collecting. In general, in qualitative } \\
\text { research, researcher uses data collection techniques through interviews, } \\
\text { observations, and document studies. The results showed: (1) That the } \\
\text { MAN } 2 \text { Model Medan Madrasa teacher was a professional teacher. } \\
\text { Teacher professionalism correlates with the quality of educational } \\
\text { products. Professional teachers make education or a quality learning } \\
\text { process, so students are happy to participate in the learning process, so } \\
\text { that human resources are produced from quality madrasa graduates, (2) } \\
\text { Generally the teachers at MAN } 2 \text { Model Medan apply various models of } \\
\text { learning both learning cooperative and technology-based learning, (3) } \\
\text { That there are two learning strategies that are always carried out by } \\
\text { teachers in implementing the learning and teaching process, namely } \\
\text { cooperative learning and technology-based learning, the number of } \\
\text { teachers in MAN } 2 \text { Model Medan have been certified and have better } \\
\text { career paths. This can be seen from the large number of teachers who have } \\
\text { undertaken higher education, namely Masters. improve the quality } \\
\text { management function in the madrasa in its leadership, the processes of } \\
\text { the quality management function are carried out, namely: Planning, } \\
\text { organizing, Scavenging, and monitoring. }\end{array}$ \\
\hline Kata Kunci & Competence, Professional, Teacher, Cooperative Learning \\
\hline How to cite & $\begin{array}{l}\text { Riduan Pohan \& Muhammad Rizki, (2021). Manajemen Mutu Dalam } \\
\text { Peningktaan Kompetensi Profesional Guru Di Man } 2 \text { Model Medan. } \\
\text { Jurnal Journal of Education and Teaching Learning (JETL). }\end{array}$ \\
\hline
\end{tabular}

\section{PENDAHULUAN}

Guru merupakan peran induk dalam memajukan suatu pendidikan yang mana memberikan ilmu pengetahuannya kepada peserta didik. Guru memiliki peranan sesuai dengan fungsi yang terdapat dalam UU No. 14 tahun 2005 pasal 4 yang berbunyi "untuk meningkatkan martabat dan peran guru sebagai agen pembelajaran berfungsi untuk meningkatkan mutu pendidikan nasional". Mutu pendidikan tak lepas dari peran guru untuk memajukan Pendidikan baik formal dan informal. Dalam proses mengukur mutu Pendidikan pada guru 
adalah mengetahui 4 kompetensi, yaitu kompetensi pedagogik, kompetensi profesional, kompetensi sosial dan kompetensi kepribadian. Dalam mengukur keempat kompetensi tersebut diharapkan seorang guru dapat menjaga kualitas profesionalismenya baik itu di dalam sekolah maupun di luar. Menjaga suatu profesionalisme guru membutuhkan kesadaran yang tinggi akan tugas dan fungsinya seorang guru.

Secara umum, ada tiga tugas guru sebagai profesi, yakni mendidik, mengajar, dan melatih. Sebagai pengajar, guru dituntut mempunyai wewenang mengajar berdasarkan kualifikasi sebagai tenaga pengajar. Sebagai tenaga pengajar, setiap guru sebagiknya memiliki profesionalisme dalam bidang pembelajaran. Setiap usaha peningkatan kompetensi dan profesional guru akan memberi hasil dengan baik jika diikuti oleh kompetensi dan motivasi guru untuk meningkatkan dan mengembangkan kemampuannya sendiri. Asrorun Ni'am (2006:42) mengungkapkan bahwa upaya peningkatan kompetensi guru harus mendasarkan pada kemauan dan kemampuan guru.Oleh karena itu, perlu disusun standar profesional guru yang akan dijadikan acuan pengembangan mutu guru.

Glickman (2004:51) dalam Bafadal menyebutkan aspek pada guru yang menentukan orientasi profesionalnya, yaitu komitmen guru, aspek tersebut harus melekat pada diri seorang guru, karena ia akan menentukan tipe guru tersebut dalam melaksanakan proses pembelajaran.

Kompetensi guru pada umumnya cukup kompleks, sehingga baik dalam pendidikan prajabatan maupun selama berada dalam pekerjaannya dituntut sejumlah pengetahuan dan seperangkat keterampilan tentang jabatannya. Guru dituntut untuk melaksanakan berbagai tugas edukatif dan tugas administratif. Setiap guru memiliki kelebihan dan keterbatasan kemampuan dalam melaksanakan tugasnya. Hal ini ditentukan oleh latar belakang pengetahuan, keterampilan dan motivasinya. Kemampuan guru dalam melaksanakan tugasnya dapat ditingkatkan melalui kompetensi dan supervisi secara teratur dan terencana. Kompetensi atau kemampuan terdiri dari pengalaman dan pemahaman tentang fakta dan konsep, peningkatan keahlian, juga mengajarkan perilaku dan sikap. Kompetensi juga merupakan perilaku rasional guna mencapai tujuan yang dipersyaratkan sesuai dengan kondisi yang diharapkan.

Upaya pengembangan profesi guru sebenarnya telah banyak dilakukan oleh pemerintah, mulai dari pembaharuan LPTK yang mengarahkan pendidikan calon guru untuk penguasaan kompetensi tertentu, pembaharuan Undang-Undang Sistem Pendidikan Nasional (UU No. 20/2003), yang kemudian diikuti dengan penerbitan PP No. 19/2005 tentang Standar Nasional 
Pendidikan (SNP) yang salah satu isinya adalah tentang standar tenaga kependidikan, sampai perkembangan terakhir dengan diterbitkannya UU No. 14/2005 tentang guru dan dosen, yang menjadi dasar pijakan utama pengembangan profesionalisasi guru.

Dari sinilah peneliti tertarik melakukan penelitian tentang manajemen mutu dalam hubungannya dengan peningkatan kompetensi profesional guru. Berdasarkan pengamatan peneliti bahwa MAN 2 Model Medan selama ini telah menerapkan manajemen mutu namun belum begitu maksimal, hal ini dapat dibuktikan dengan melihat adanya salah satu komponen kompetensi yang belum berfungsi sebagaimana mestinya yaitu dalam hal penempatan pegawai, peningkatan kompetensi guru dan masih ada guru-guru yang belum mempunyai kompetensi yang cukup agar terjaminnya manajemen mutu pendidikan sekolah lebih baik.

\section{Konsep Mutu}

Istilah mutu dalam Kamus Besar Bahasa Indonesia mengandung arti ukuran baik untuk suatu benda, kadar, taraf atau derajat, untuk kependidikan adalah derajat kecerdasan, kualitas, meningkatkan pendidikkan. Selanjutnya kata mutu dalam Kamus Ilmiah Populer, berarti kualitas, derajat atau tingkat.7 Sejalan dengan itu, menurut Garvin, (2005:93) mutu atau kualitas adalah suatu kondisi dinamis yang berhubungan dengan produk, pelayanan, orang, proses dan lingkungan yang memenuhi atau melebihi apa yang diharpkan. Daulat Tampubolon, (2011:108) mengartikan mutu sebagai paduan sifat-sifat produk, yang menunjukan kemampuannya dalam memenuhi kebutuhan pelanggan langsung atau tidak langsung baik kebutuhan yang dinyatakan maupun yang tersirat, masa kini dan masa depan.

Kualitas dapat dipahami sebagai perbaikan terus-menerus. Kualitas dapat berarti keunggulan. Kualitas dapat berarti pemenuhan harapan pelanggan. Hansen dikutip Naronha, (2002:13) menyatakan bahwa sampai saat ini konsep kualitas diartikan terfragmentasi dan ambigu baik dalam literatur maupun dalam praktik. Setelah melakukan pencarian literatur Hansen telah mengidentifikasi lima definisi utama yaitu, kualitas sebagai produk, kualitas sebagai mana pandangan konsumen, kualitas sebagai pemenuhan harapan pelanggan, kualitas sebagai nilai, dan kualitas sebagai adaptasi terhadap teknis spesifikasi atau manufaktur.

\section{Manajemen Mutu}

Manajemen mutu dalam pendidikan telah dinyatakan oleh Sallis, bahwa : "Quality Management is abou creating a quality culture where the aim of every member of staff is to delight their customer, and where the stucture of their organization alloe to do so". Mengandung pengertian bahwa manajemen mutu 
(Quality Management) berhubungan dengan penciptaan budaya kualitas, di mana guru dan stap berusaha menyenangkan hati pelanggan sesuai dengan tujuan organisasi.

Dalam upaya untuk meningkatkan kualitas yang diinginkan dengan didasarkan pada kepuasan pelanggan, maka diperlukan strategi penerapan manajemen mutu yang tepat agar tujuan yang telah direncanakan tercapai secara maksimal. Untuk bisa menyenangkan konsumen atau pelanggan dalam pendidikan maka perlu perbaikan sekolah yang mungkin dilakukan secara lebih kreatif dan konstruktif, dan yang paling penting adalah bagaimana mutu dalam programnya dapat mengubah kultur sekolah agar peserta didik dan orang tuanya menjadi tertarik dengan adanya inovasi yang ditimbulkan oleh manajemen mutu.

\section{Standar Mutu Pendidikan}

Secara nasional diberlakukanlah standar-standar mutu pendidikan, yang disebut Standar Nasional Pendidikan (SNP). Dalam pasal 2 ayat 1 PP No. 19 tahun 2005 dinyatakan bahwa ruang lingkup SNP meliputi: (1) standar isi; (2) standar proses; (3) standar kompetensi lulusan; (4) standar pendidik dan tenaga kependidikan; (5) standar sarana dan prasarana; (6) standar pengelolaan sekolah; dan (7) standar pembiayaan.

Standar penilaian pendidikan menurut PP No. 19 tahun 2005 Pasal 1 Ayat (11) adalah standar nasional pendidikan yang berkaitan dengan mekanisme, prosedur, dan instrumen penilaian hasil belajar peserta didik. Di dalam Pasal 63 ayat (1) dikemukakan penilaian pendidikan pada jenjang pendidikan dasar dan menengah terdiri atas(a) penilaian hasil belajar oleh pendidik, (b) penilaian hasil belajar oleh satuan pendidikan, dan (c) penilaian hasil belajar oleh Pemerintah.

Penilaian hasil belajar oleh satuan pendidikan bertujuan menilai pencapaian standar kompetensi lulusan untuk semua mata pelajaran pada kelompok mata pelajaran agama dan akhlak mulia, kelompok mata pelajaran kewarganegaraan dan kepribadian, kelompok mata pelajaran estetika, dan kelompok mata pelajaran jasmani, olahraga, dan kesehatan. Penilaian ini merupakan penilaian akhir untuk menentukan kelulusan peserta didik dari satuan pendidikan. Penilaian hasil belajar untuk semua mata pelajaran pada kelompok ilmu pengetahuan dan teknologi dilakukan melalui ujian sekolah/madrasah untuk menentukan kelulusan peserta didik dari satuan pendidikan. Dalam penelitian ini, aspek standar penilaian pendidikan difokuskan pada tiga hal, yaitu (1) Mekanisme penilaian hasil belajar, (2) Prosedur penilaian hasil belajar, dan (3) Instrumen penilaian hasil belajar. 
Page 1-12

\section{Kompetensi Guru}

Menurut Undang-undang No. 14 tahun 2005 tentang guru dan dosen pada pasal 10 ayat (1) menyatakan terdapat kompetensi guru yaitu : kompetensi Pedagogik, kompetensi Kepribadian, kompetensi social dan kompetensi profesional yang diperoleh melalui Pendidikan profesi. Dalam hal ini pun tertulis pada hadis bagi seorang guru yaitu :

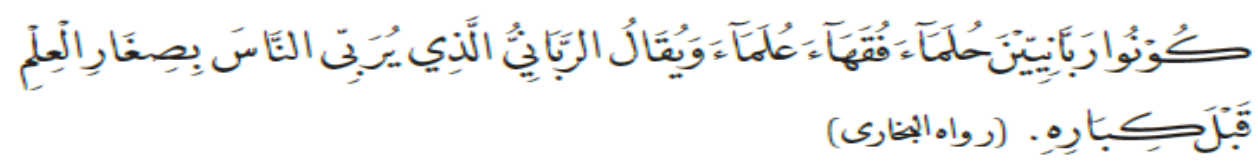

"Jadilah pendidik yang penyantun, jadilah fiqaha dan ulama; disebut pendidik bila seseorang mendidik manusia dengan Memberikan ilmu sedikitsedikit lama-lama menjadi banyak." (HR. Bukhari)

\section{Kompetensi Profesional}

Menurut Uno, (2007:18) kompetensi profesional guru adalah seperangkat kemampuan yang harus dimiliki oleh seorang guru agar ia dapat melaksanakan tugas mengajar dengan berhasil. Sedangkan menurut Tilaar, (2002:89) kompetensi profesional yang perlu dimiliki oleh setiap guru antara lain: kemampuan untuk mengembangkan kepribadian pribadi peserta didik, khususnya kemampuan intelektualnya, serta membawa peserta didik menjadi anggota masyarakat Indonesia yang bersatu berdasarkan Pancasila.

Guru profesional adalah guru yang mampu mengelola dirinya sendiri dalam melaksanakan tugas sehari-hari. Guru yang kompeten akan lebih mampu menciptakan lingkungan belajar yang efektif dan mampu melaksanakan tugas secara optimal untuk kepentingan pencapaian hasil belajar siswa khususnya dan pencapaian mutu pendidikan pada umumnya. Hal ini punterdapat pada hadis yang berbunyi :

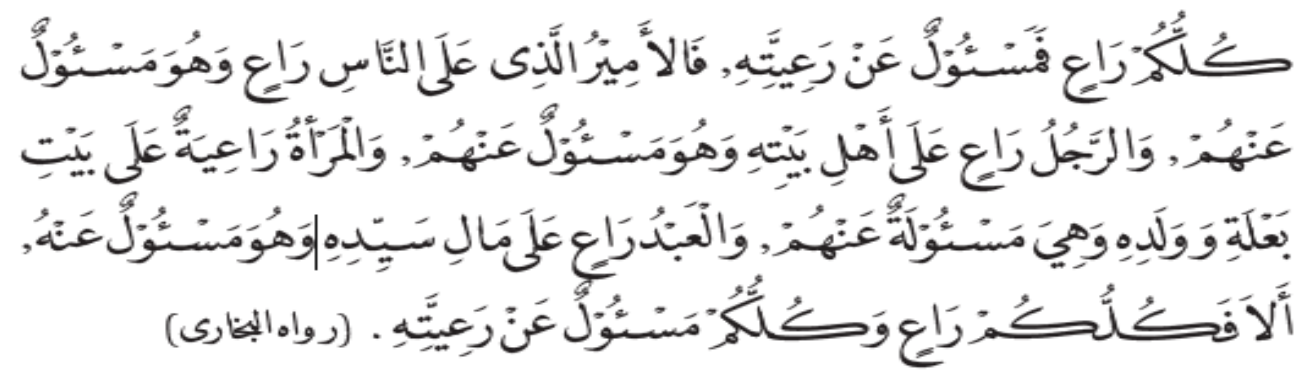

tentang kepemimpinan kalian, penguasa yang memimpin rakyatnya adalah pemimpin dan akan diminta pertanggungjawaban atas kepemimpinannya, seoarang suami adalah pemimpin bagi keluarganya dan ia akan dimintai pertanggugjawaban atas kepemimpinnanya, seorang isteri 
adalah pemimpin rumah suaminya serta anaknya dan ia akan dimintai pertanggungajawaban atas kepemimpinannya, seorang pelayan adalah pemimpin harta majikannya dan ia akan dimintai pertanggungjawaban atas kepemimpinannya." (HR. Bukhari)

komponen kompetensi profesional guru yaitu: (1) penguasaan materi ajar, (2) Kemampuan mengelola pembelajaran, (3) pengetahuan tentang evaluasi. Ketiga kelompok kompetensi ini pada dasarnya merupakan hasil kerja kognitif seorang guru. Sarwono mendefinisikan kognitif sebagai kognisi yaitu bagian dari jiwa manusia yang mengolah informasi, pengetahuan, pengalaman, dorongan, perasaan, dan sebagainya baik yang datang dari luar maupun dari dalam diri sendiri membentuk simpulan-simpulan yang menghasilkan perilaku.

\section{METODOLOGI PENELITIAN}

Penelitian ini dilaksanakan di MAN 2 Model Medan yang berlokasi di Jl. Williem Iskandar No.7A, Kelurahan Sidorejo, Kec. Medan Tembung, Kota Medan, Sumatera Utara. Dipilihnya MAN 2 Model Medan sebagai tempat penelitian karena MAN 2 Model Medan Adalah Madasah Aliyah yang telah mendapat predikat Akreditasi A dan meningkatnya prestasi peserta didik baik di bidang akademik maupun non akademik setiap tahunnya. MAN 2 Model Medan telah berdiri sejak tahun 1992 dan telah mengalami pergantian kepala sekolah sebanyak 9 kali. Jumlah tenaga pendidik 149 orang dengan rincian 85 PNS dan 64 GTT, dan siswa 2428 orang dengan rincian kelas X jumlah siswa 785 orang, kelas XI jumlah siswa 781 orang dan kelas XII jumlah siswa 870 orang. Pelaksanaan penelitian ini pada bulan November 2020.

Jenis penelitian ini adalah merupakan penelitian deskriftif kualitatif yaitu prosedur penelitian yang menghasilkan data deskriptif berupa kata-kata tertulis atau lisan dari orang-orang dan pelaku yang diamati, diarahkan dari latar belakang individu secara utuh (holistic) tanpa mengisolasikan individu dan organisasinya dalam variable tetapi memandangnya sebagai bagian dari suatu keutuhan. Penelitian kualitatif sering pula disebut metode etnografik, metode fenomenologis, atau metode impresionistik. Rancangan penelitian kualitatif dengan cara membaca berbagai informasi tertulis, gambar-gambar, berfikir dan melihat objek dan aktifitas orang yang ada disekelilingnya dengan cara melakukan wawancara dan sebagainya.

Jenis data dalam penelitian ini terdiri atas dua, yakni data yang bersifat primer dan data yang bersifat sekunder. Data primer adalah data yang diperoleh langsung dari kepala sekolah, guru dan siswa. Data tersebut diperoleh melalui wawancara yang dilakukan oleh peneliti. Data sekunder 
adalah data yang peneliti peroleh dari kepala tata usaha, pegawai administrasi dan stakeholders pendidikan yang terkait melalui wawancara. Penelitian ini menggunakan Teknik pengumpulan data melalui wawancara, observasi, dan studi dokumen. Instrumen penelitian merupakan prosedur teknis yang praktis digunakan dalam mengumpulkan data di lapangan dengan cara mengumpulkan informasi melalui catatan, rekaman, blangko penelitian, dan pedoman pertanyaan.

\section{HASIL DAN PEMBAHASAN}

\section{Kompetensi Profesional Guru Di Man 2 Model Medan}

Berdasarkan hasil observasi yang dilakukan oleh guru di MAN 2 Model Medan. Bahwa strategi pembelajaran yang dilakukan yaitu Cooperatif learning dan Blended Learning. a. Metode Pembelajaran di MAN 2 Model Medan. Metode pembelajaran merupakan bagian dari strategi pembelajaran, metode pembelajaran berfungsi sebagai suatu cara dalam menyajikan, menguraikan, memberikan contoh, dan latihan-latihan berupa soal-soal kepada siswa agar timbulak tujuan dalam pembelajaran. Metodemetode yang sering digunakan dalam pembelajaran di MAN 2 Model Medan sangatlah bervariasi. Hal ini terlihat dalam keaktifan siswa (student Learning) dan dibarengi dengan berbasis teknologi (e-Learning) dalam metode pembelajaran. Kegiatan pembelajaran di MAN 2 Model Medan umumnya dilaksanakan melalui tahapan-tahapan sebagai berikut:

- Melakukan Pendekatan pembelajaran, Pendekatan pembelajaran diartikan sebagai titik tolak atau sudut pandang terhadap proses pembelajaran, yang merujuk pada pandangan tentang terjadinya suatu proses yang sifatnya masih sangat umum, di dalamnya mewadahi, menginsiprasi, menguatkan, dan melatari metode.

- Menentukan strategi dan metode pembelajaran. Strategi pembelajaran adalah suatu kegiatan pembelajaran yang harus dikerjakan guru dan siswa agar tujuan pembelajaran dapat dicapai secara efektif dan efisien. Strategi pembelajaran sifatnya masih konseptual dan untuk mengimplementasikannya digunakan metode pembelajaran.

- Metode pembelajaran dijabarkan ke dalam teknik dan gaya pembelajaran. Dengan demikian, teknik pembelajaran dapat diatikan sebagai cara yang dilakukan seseorang dalam mengimplementasikan suatu metode secara spesifik. Misalkan, penggunaan metode ceramah pada kelas dengan jumlah siswa yang relatif banyak membutuhkan teknik tersendiri, yang tentunya secara teknis akan berbeda dengan penggunaan metode ceramah pada kelas yang jumlah siswanya terbatas. 
Secara sederhana, strategi pembelajaran guru di MAN 2 Model dan, sebagai berikut :

Gambar 4.3

Strategi dan Metode Pembelajaran Guru MAN 2 Model Medan

\begin{tabular}{|c|c|c|c|}
\hline $\begin{array}{c}\text { Pendekatan } \\
\text { Pembelajaran }\end{array}$ & strategi & Metode \\
\end{tabular}

\section{Pelaksanaan Manajemen Mutu Guru di MAN 2 Model Medan}

Berdasarkan hasil wawancara dengan bapak Kepala Madrasah, mutu pembelajaran di MAN 2 Model

Medan relatif baik, hal ini dapat dibuktikan dengan:

- Proses pembelajaran dilaksanakan sesuai dengan prosedur yang semestinya yaitu, Kegiatan pendahuluan pembelajaran, Kegiatan Inti Pembelajaran dan Kegiatan Akhir Pembelajaran.

- Guru memiliki kemampuan dalam pengembangan pembelajaran pada setiap mata pelajaran yang diajarkan, Sewaktu Pembelajaran berlangsung guru menerapkan berbagaikan strategi, teknik dan kaedah sehingga siswa dapat memahami dan menguasai materi yang diajarkan.

- Keaktifan siswa dalam mengikuti proses pembelajaran. Suasana kondusif di dalam kelas merupakan faktor utama untuk menarik minat siswa terhadap pelajaran, disamping metode yang digunakan oleh guru. Di Madrasah ini siswa aktif dalam pembelajaran karena guru menggunakan berbagai metode.

- Pemanfaatan media pembelajaran yang sesuai. Sebagian guru telah mengguasai dan menggunakan laptop dan infocus dalam pembelajaran, sehingga pembelajaran menjadi lebih menarik kerana siswa diberikan sajian ilmu dengan cara yang menarik perhatian. Guru hanya bertindak sebagai fasalitator dengan memantau siswa dan menerangkan beberapa masalah yang tidak di fahami oleh para siswa.

- Prestasi siswa.

Dapat diketahui bahwa prestasi yang diraih oleh para guru dan siswa berupa kegiatan formal dan informal yang pada hakikatnya menyentuh pembelajaran yang sesungguhnya sebagaimana yang tertuang dalam tujuan pembelajaran, namun demikian kondisi tersebut dapat digunakan sebagai barometer bahwa madrasah sebagai Lembaga Pendidikan telah berupaya untuk meningkatkan lemampuan siswa-siswinya, baik secara 
kognitif, afektif maupun psikomotorik. Hal itu terbukti dengan hasil wawancara yang dilakukan

oleh WKM kurikulum bahwa MAN 2 Model Medan memiliki output sebanyak 64\% yang dulunya 35\% untuk masuk ke PTN se-Indonesia. Berdasarkan hasil observasi, umunya guru-guru di MAN 2 Model

Medan menerapkan berbagai model pembelajaran baik itu pembelajaran kooperatif dan pembelajaran berbasis teknologi. Dalam pembelajaran baik secara kooperatif dan berbasis teknologi, guru selalu memberikan timbal balik (feedback) agar timbulnya kesesuaian pembelajaran dengantujuan pembelajaran agar menemukan mutu pembelajaran yang timbul dari siswa itu sendiri.

\section{Upaya yang dilakukan untuk Peningkatan Kompetensi Profesional Guru di} MAN 2 Model Medan

Dari hasil wawancara yang disampaikan oleh WKM Kurikulum bahwa MAN 2 Model Medan berhasil meningkatkan mutu hasil lulusan dengan output sebanyak $64 \%$ dengan kerjasama antar siswa dan guru

dalam proses pembelajaran. Jadi guru dalam pembelajaran memiliki peran yang sangat strategis. Jika kepala madrasah adalah penentu kebijakan dalam lembaga, maka guru adalah pelaksana dan orang yang terjun langsung dalam proses pendidikan yang berada dalam kelas. Hasil penelitian menunjukan bahwa upaya guru dalam meningkatkan profesionalismenya adalah dengan mengikuti kegiatan Musyawarah Guru Mata Pelajaran (MGMP), penataran, Workshop dan pelatihan-pelatihan.

Hasil penelitian yang dilakukan di MAN 2 Model Medan melalui wawancara terhadap pengembangan profesionalismenya adalah mengikuti kegiatan-kegiatan baik di dalam madrasah maupun diluar madrasah. Seperti ikut serta dalam kegiatan Musyawarag guru Mata Pelajaran (MGMP), diklat, Workshop dan perlombaan-perlombaan. Dalam pengembangan nya guru haruslah aktif dalam menjalankan kompetensi khususnya kompetensi profesional sesuai dengan bidangnya masingmasing. Oleh karena itu, guru haaruslah menyempurnakan dirinya dalam berbagai suatu aspek agar mendukung kompetensi profesionalnya.

Guru tidak hanya berkewajiban menyampaikan materi saja kepada siswa, namun juga berkewajiban menyampaikan kemampuan (skill) dan nilai-nilai. Hal ini berarti guru tugas bukan hanya dari pengetahuannya saja (knowledge) saja, akan tetapi juga dapat menjadi contoh yang teladan bagi siswanya. Oleh karena itu, secara spesifik guru harus mempunyai kompetensi profesional. Guru profesional dapat diartikan memiliki pengetahuan yang luas dan mendalam mengenai bidang studi yang 
ditransformasikan kepada siswa di madarasah serta penguasaan dalam menyampaikan pengetahuan, sikap serta keterampilannya yang vital bagi seorang guru.Kepala Madrasah sebagai pemimpin di Madrasah memiliki tanggung jawab yang besar dalam menggerakkan seluruh sumber daya yang ada dimadrasah, sehingga melahirkan etos kerja dalam mencapai tujuan.

Adapun hasil yang diperoleh dari penelitian ini tentang upaya kepala madrasah dalammeningkatkan kompetensi profesional guru sebagaimana disampaikan oleh Bapak Kepala Madrasah sebagai berikut :

- Pembinaan Kompetensi Guru

- Penyediaan sumber-sumber dan media-media belajar di madrasah

- Pengelolaan lingkungan belajar yang kondusif

- Pembangunan e-learning

- Pengolaan mutu pendidikan dimadrasah, serta

- Pembinaan siswa

\section{KESIMPULAN}

Suatu pelayanan yang baik kepada masyarakat secara otomatis akan membenatu segala kebutuhan yang diinginkan oleh pihak madrasah. Dan akan secara langsung pula mengarah kepada mutu pendidikan dimadrasah. Kompetensi professional seorang guru di MAN 2 Model Medan untuk dapat meningkatkan mutunya dapat disimpulkan sebagai berikut :

1. Kompetensi guru di MAN 2 Model Medan relative baik, hal ini terlihat dari predikat guru pada sarjana, magister dan ada yang melanjutkan doktor, predikat guru pada pembelajaran yang digunakan, model-model pembelajaran yang inovatif, sudah sertifikasi, dan ada yang berprestasi dalam tingkat nasional. Suatu kompetensi dapat mempengaruhi mutu pendidikan di MAN 2 Model Medan sehingga terjaminnya kualitas mutu itu sendiri.

2. Pelaksanaan manajemen mutu di MAN 2 Model medan terlihat dari strategi pembelajaran dan metode yang bervariasi hingga memakai teknologi dalam proses pembelajaran yang di gunakan oleh guru-guru di MAN 2 Model Medan. Sehingga tercapainya tujuan pembelajaran sesuai dengan mutu pendidikan.

3. Upaya-upaya yang dilakukan pimpinan madrasah untuk meningkatkan kompetensi Profesionalnya di MAN 2 Model medan dengan cara guru dalam mengembangkan kompetensi profesionalnya yaitu terdapat dua strategi pembelajaran yang selalu dilakukan oleh guru dalam melaksanakan proses belajar dan mengajar, yaitu pembelajaran kooperatif 
dan pembelajaran berbasis teknologi, banyaknya guru-guru di MAN 2 Model medan sudah sertifikasi dan memiliki jenjang karir lebih tinggi. Hal itu dapat terlihat dari banyaknya jumlah guru yang sudah menjalankan pendidikannya lebih tinggi yaitu Magister. meningkatkan fungsi manajemen mutu di madrasah dalam kepemimpinananya maka dilakukanlah proses-proses fungsi dari manajemen mutu itu sendiri, yaitu : Perencanaan, pengorganisasiaan, Pengerakan, dan pengawasan Medan.

\section{DAFTAR PUSTAKA}

Garvin, David di dalam Nasution, S. 2005. Manajemen Peningkatan Mutu Pendidikan Berbasis Sekolah. Jakarta ; Depdikbud Depdikbud.

Kreitner, R. 1989. Management. Boston : Houghton Mifflin Company.

Naronha, C. 2002. The Theory of Culture-specific Total Quality Management : Quality management in Chinese Regions. New York: Palgrave.

PP No. 19 Tahun 2005 tentang Standar Nasional Pendidikan

Sallis, 2006. Total Quality Manageman in Education. Yogyakarta : IRCISOD.

Siregar, E., Syafaruddin, \& Zaini, M. F. (2020). The Leadership Of The School In

Development Quality Culture In Student Learning In Mts State 2 Medan.

International Journals of The Social Science, Education and Humanities, 1(3). https://doi.org/https://doi.org/10.46576/ijsseh.v1i3.952

Sugiyono, 2009. Metode Penelitian Kuantitatif Dan Kualitatif dan R dan D. Bandung : ALFABETA.

Sujana, N. 2004. Penelitian dan Penilaian Pendidikan. Bandung : Sinar Baru Algesindo.

Tampubolon, DP. 2011. Perguruan Tinggi Bermutu:Paradigma Baru Manajemen Pendidikan Tinggi Menghadapi Abad ke-21. Jakarta : PT. Gramedia Pustaka Utama.

Terry, G R. 2002. Principle of Management . Georgetown: Richard D. Irwing Inc.

Tilaar, HAR. 2002. Membenahi Pendidikan Nasional. Jakarta: PT Rineka Cipta. Undang-Undang No. 14 Tahun 2005 tentang Guru dan Dosen

Uno, HB. 2007. Profesi Kependidikan Problema, Solusi dan Reformasi Pendidikan di Indonesia. Jakarta: Bumi Aksara

Zaini, M. F., \& Syafaruddin, S. (2020). The Leadership Behavior of Madrasah Principals in Improving the Quality of Education in MAN 3 Medan. Jurnal Iqra': Kajian Ilmu Pendidikan, 5(2), 95-106. https://doi.org/10.25217/ji.v5i2.649 